\title{
International problems in science and technology studied in Japan
}

\section{Tokyo}

A report issued last week by a committee of leading Japanese academics and industrialists calls on Japan to initiate largescale international research projects and to promote the exchange of data and development of science and technology on a global scale.

The report, entitled Summary of International Problems in Science and Technology, was prepared by a subcommittee of the Council of Science and Technology, Japan's top science policy-making body which is chaired by Prime Minister Noboru Takeshita. The subcommittee's recommendations are intended to meet obligations under the recently signed USJapan Science and Technology Agreement. But they are also intended to counter US moves to restrict the use of advanced technology for trade and/or military reasons.

The Human Frontier Science Program is cited in the report as an example of the type of international project Japan should initiate. And at the council meeting last week where the report was presented, Takeshita urged the heads of the Foreign Ministry and the Science and Technology Agency to make every effort to implement the Frontier programme. (The agency and the Ministry of International Trade and Industry have applied for about $\$ 20$ million in fiscal year 1989 to establish a foundation in Europe that will distribute grants and fellowships for international research on the brain and molecular recognition.)

To facilitate Japan's participation in international research projects, the subcommittee calls on the government to put more money into basic research; to establish a new system for research evaluation so that those who carry out good research are amply rewarded; to upgrade the environment of research facilities, for example by employing more technicians (technicians are noticeably absent in Japanese universities); to create a more flexible research management system that will encourage the flow of researchers between institutes within and outside Japan; and to establish world-class 'centres of excellence' in Japan.

Hiroshi Inose, director of the National Center for Scientific Information Systems, suggests in the appendix to the report that Japan should set up a large "Institute for Useless Research". The institute would award funds for research that is untied to applications, economic considerations, efficiency or success. This suggestion contrasts with developments in the West where governments are trying to tie research to industry.

To encourage the influx of foreign scientists to Japan, the subcommittee recommends the introduction of new fellowship and workshop programmes and the establishment of Japanese language-teaching facilities both within and outside Japan. During negotiations of the US-Japan Science and Technology Agreement, one US negotiator suggested that Japan should pay all language tuition expenses for US scientists. Inose, in his personal remarks in the report's appendix, says he finds this suggestion "cute" and he thinks Japan should meet it by establishing language-training centres in major cities of the world. Inose suggests that the centres be modelled along the lines of West Germany's Goethe Institut.

Intellectual property rights were another contentious issue in negotiations of the science and technology agreement. In the agreement this problem is left to solution on a 'case by case' basis. The subcommittee report says that it has been difficult to reach international agreement on intellectual property rights because of their relationship to economic power and national security.

Japan is particularly concerned about provisions in the new US omnibus trade bill which will make it easier for the United States to impose import restrictions on technology that is judged to violate patents held by US companies and citizens. The subcommittee calls for the developed nations "to walk in pace" to reach a "new consensus" on rules for intellectual property rights.

But the issue of most concern to members of the subcommittee is US moves to restrict technology for military reasons. Both Inose and Junosuke Kishida in the appendix to the report mention a list of "military critical technology" prepared by the US Department of Defense under the recommendations of the Bucy report. Inose and Kishida fear that this list, which is classified, covers virtually all leading-edge technology including dual-use technology which can be used for both civilian and military purposes. And Inose says Japan would be in a "very difficult" position if this list is used to keep technology secret

The council report recommends that Japan should promote the free exchange of data on a global scale and should continue to concentrate on development of science and technology in the civilian sector. And Inose urges Japanese government officials to continue to do their utmost in negotiating with the United States over the science and technology agreement so that the agreement is a "plus" for Japan. If they fail, it could be "a great disaster".

\section{Field tests end}

One of the first experiments approved in the United States involving the environmental release of a genetically engineered organism has been ended prematurely by its company sponsor. BioTechnica, a biotechnology company based in Cambridge, Massachusetts, has halted its field test of a strain of Rhizobium meliloti engineered to have enhanced nitrogen fixing capabilities because the microbe failed to increase the growth of alfalfa.

Despite local controversy, BioTechnica began the field test of the recombinant $R \mathrm{hi}$ zobium last spring on a plot of alfalfa at a farm owned by the company in Pepin County, Wisconsin (see Nature 327, 90; 1987). The bacterium contained plasmids bearing several copies of the gene for the production of the enzyme nitrogenase, and was administered to the alfalfa plants in irrigation water. By the end of the growing season, the company could not detect the presence of the recombinant organism in the soil or the root nodules of the alfalfa plants, and plants treated with the engineered Rhizobium grew no faster than those left untreated.

BioTechnica plans to try again next year using Rhizobium with extra nitrogenase genes integrated into its genome, and coated onto the alfalfa seeds or poured into the furrow as the seeds are planted. C.E

\section{What's in a name?}

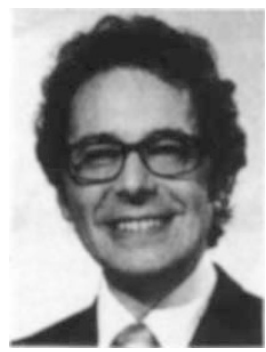

THE name of Professor Alec Boksenberg has joined the classical heroes in the sky after a ceremony at the mediaeval castle of Herstmonceux, home of the Royal Greenwich Observatory, when an asteroid was named after the observatory's director. The asteroid, $12-15 \mathrm{~km}$ in diameter was discovered in 1979 by Eleanor Helin, an astronomer at the Jet Propulsion Laboratory in Pasadena. It goes under the official name of Asteroid (3205) Boksenberg 1979M06.

C.McG.

\section{Kingsbury resigns}

DAvid Kingsbury, assistant director of the National Science Foundation for Biological, Behavioral and Social Sciences, has resigned with effect from 15 October. Over the past year, Kingsbury has been the target of an investigation by the Justice Department of a potential conflict of interest regarding his relationship with a private pharmaceutical company. Kingsbury says he is resigning in order to pursue his research interests in slow viruses. He will join the faculty at George Washington University where he currently has a laboratory. 